International Research Journal of Management, IT \& Social Sciences
Available online at https://sloap.org/journals/index.php/irjmis/
Vol. 7 No. 3, May 2021, pages: 265-273
ISSN: 2395-7492
https://doi.org/10.21744/irjmis.v8n3.1658

\title{
Understanding Human Resources Management Strategy in Implementing Good Government Practice: What Research Evidence Say
}

\author{
Achmad Hidir ${ }^{a}$ \\ Arif Zunaidi $^{b}$ \\ Petrus Jacob Pattiasina ${ }^{\mathrm{c}}$
}

Article history:

Submitted: 27 March 2021

Revised: 18 April 2021

Accepted: 7 May 2021

\section{Keywords:}

good government practices;

HR management;

public services;

research evidence;

\begin{abstract}
Understanding human resource development strategies in good governance service practices are essential. For this reason, we have reviewed several study pieces of evidence to add to the enrichment of our study. The reading sources we are looking for are data-based sources from Google scholars, ERIC publications, and other literature sources. Furthermore, we take the analysis stage by involving the coding system, evaluation, data extract, in-depth interpretation, and drawing conclusions that are valid findings and high reliability because these findings have answered the questions and danced the hypothesis of this study. We depend on secondary data and descriptive qualitative study designs. Based on the discussion of the findings data, we can conclude that the HR governance strategy working in public service organizations is not only required for superior competence, technical skills, and mastery of the underlying laws and regulations, but they are state apparatuses that are even more crucial in shaping mental and behavioral professional, friendly in nurturing, honest, sympathetic, wise, intelligent, and highly responsible.
\end{abstract}

International research journal of management, IT and social sciences (C) 2021. This is an open access article under the CC BY-NC-ND license (https://creativecommons.org/licenses/by-nc-nd/4.0/).

\section{Corresponding author:}

Zunaidi, A.

Institut Agama Islam Negeri Kediri, Indonesia.

Email address: arifzunaidi@iainkediri.ac.id

\footnotetext{
FISIP Universitas Riau, Indonesia.Email: achmad.hidir@lecturer.unri.ac.id

Institut Agama Islam Negeri Kediri, Indonesia. Indonesia.

Universitas Pattimura, Indonesia. Email: pattiasinaethus@gmail.com
} 


\section{Introduction}

To understand the mastery of the state constitution and see the essence of governance, the public agency has stipulated the stipulation as Law Number 25 of 2009 concerning Public Services, (Larsen \& Piché, 2009; Anderson \& Merna, 2003) as an effort to improve quality and ensure the administration of governance as a whole, Good administrative standards are the same as providing guarantees to every resident from all forms of coercion (Rahmadana et al., 2020; Gao et al., 2008). As an encouragement to improve the nature of government administrators, it is necessary to expand the limits of administrative, human resources, considering that (HR) administrative staff has an essential task as a vital influence on regulatory changes (Ashari, 2010; Fridayanti et al., 2019; Yahya et al., 2020; Hemi et al., 2014). According to Azhari, reforming the state apparatus's implementation and governance is a prerequisite for the bureaucratic governance expected by law. The title of the improvement strategy in state machine assemblies is to expand polished skills, impartiality, and assistance in human resource management from the government to feel the benefits. Improving the quality of human resources tools aims to recognize capable, impartial, fair, and prosperous human resources. This shows the increasing importance of efforts to build administrative faculty boundaries to improve the sustainable nature of public administration (Putra, 2018; Ristiandy, 2020; Syakdiyah et al., 2019; Choi \& Lee, 2002). This is an innovation in public services in an era with disruption to all sectors of public services.

Seeking deep understanding to improve the nature of government administration is very urgent when the country enters an era of comprehensive reform (Rao, 2013; Larsen \& Piché, 2009; Cui et al., 2008). This is in line with the spirit of reform and development of administration and public services in developing countries entering the era of social change. So for that, it is essential to uphold solid efforts to organize more reliable human resources, such as the accessibility of offices and foundations, including support for digitizing information technology to accelerate the development of high-quality public services (Kaufman, 2020; Sukati et al., 2012). Therefore, the human resources of the public apparatus, which will organize the administration to achieve the government presentation that protects the community, must receive important consideration in improving the quality of public services.

Thus, the determination and situation of representation shown by the ability of human resources are one of the determinants of the achievement of good governance and efficiency (Seleman et al., 2014). In this public administration, the public aid apparatus must try to see and place workers and implement the idea of placing the right person in the correct position, or the right on the right place, especially in deciding the ideal individual for each structure and type of administration. In other words, the government is needed to transparently carry out a strategy of selecting and placing human resources in state apparatus, World Health Organization (2016), to be more specific by detailing precise approaches and rules concerning all prerequisites for work positions to be filled, the same as implementing a standard framework.

As a rule for the previously mentioned exercises, one of the human resources measures that can support the improvement of administrative quality is human resources that have capabilities in the field of public administration, which include responsibility and honesty; dedication to duty, health and hospitality, understanding public needs, compassion, and high moral and ethical qualities, and goodwill (Al Shobaki et al., 2017; Ahmed et al., 2018). In addition, an increase like administration in all layers can work and provide benefits for the local community if the specialist state apparatus human resources focus on several measures or features of improving the quality of administration, which include administrative skills, elegance, an inviting attitude to help, be aware of obligations being a role model, simplicity, variety in the model of assistance, accommodation, HR working openly, the administration not only requires unique talents and abilities and domination of fundamental laws and guidelines but more importantly, better mental character and behavior, better assistance friendly, authenticity, readiness, and obligation are also required (Raudeliūnienè \& Meidutè-Kavaliauskienė, 2014). He added that the analysis of factors motivates human resources in public services.

Given that the people served will not often think about the obstacles and obstacles to work, they will not often think about the problems of each representative, but they only consider what they have to serve appropriately, effectively, quickly, efficiently (Storey, 2016). Fulfillment of local areas can be achieved if human resources directly related to administration can understand and appreciate and want to offer quality support. Together, for HR administration to truly uphold the improvement of administrative quality, it is essential to properly supervise HR administration, including recognizable evidence of HR needs. Mello (2014), which is needed to offer the type of assistance predetermined assistance principles. Especially for suitability and ability for each job will be played in each help interaction. Likewise, it is essential to distinguish the requirements for the development and structuring of human assets; an increase in administrative morale is necessary so that representatives remain within established limits in offering this type of assistance (Bailey et al., 2018; Truss et al., 2013). 
Improve human resource capabilities in public service equipment; predictable arrangements are needed for event changes and increased administrative and human resource management skills through special and sustainable preparation (Osborne \& Brown, 2005). In addition, it is also essential to focus on government assistance that is representative and fair because it has an important relationship in offering the kind of quality assistance to the public that has given them the mandate and mandate as their leader. Therefore, it is essential to have a motivating framework both as an award and a penalty for government officials who uphold the order of the Constitution and their superiors. (Berman et al., 2019). Some of the problems with human assets in the benefits that make it smooth to make hierarchical progress include hard work that will generally keep service duties as usual and have no desire to acknowledge change have a culture of harm avoidance, routine duties, and an unnecessary emphasis on conventional responsibility emerging in an inflexible/moderate strategy, lack of driving force and a disincentive framework for administrative officials WHO (Battaglio Jr, 2014). Indicate elite or vice versa; and a lack of administrative, human resource capacity to lead audits in establishing appropriate assistance principles. So that efforts to help the community will be hampered.

The findings of Mahsyar (2011) that the challenges faced in public services in Indonesia in terms of the perspective of public administration services have inspired a study of the understanding of public human resources where the average skills, abilities, compassion, and morals that are very much needed are still very minimal in the state apparatus (Denhardt et al., 2013; Heady, 2001).

The condition of commitment and public services is indistinguishable from issues related to instrumental issues; more specifically, there are still differences in laws and regulations in the service sector which include, mutually exclude, between lower guidelines and more straightforward guidelines, the level of higher level, many laws and guidelines are out of date, just like any other situation for which there are no legal guidelines.

Natural problems in particular still exist in some areas, especially areas whose capabilities are still lagging behind that of different districts, individuals are still subject to work in the territory of public authority, and surprisingly are the only business openings that are accessible and promising, given the fact that the area different inaccessible. Other obstacles may include disagreements between political elites, indirect regional head election parties, local meetings, back and forth between heads and branches of authority, between central and provincial governments (Ashari, 2010). Next are things that can be verified, especially the good and bad times that occurred in the mutual assistance with the management framework from the natural period, the period of Hajj rule, the era of independence, the New Order era, to the reign of government. Change; and the last is real problems such as the condition and capacity of administrative understanding, difficulties in changing attitudes, and others related to it (Suderajat, 2012). He added that improving the strategy and human resource management system for local government officials must balance the science of constitutional expertise and the social and cultural sciences.

\section{Materials and Methods}

Understanding the evidence from human resource management strategies in implementing good governance practices in public services is the main objective of this study. We have passed through the review of dozens of publications. The search for evidence of our study is carried out by searching electronically on several data sources, such as Google Scholar and other applications. To obtain valid findings following the questions of this study, we first analyzed them by involving the data coding system, data evaluation, extracting, and in-depth interpretation to conclude the final findings. We analyze with the phenomenology approach, and we report the descriptive design. In order for our findings to be more valid and measurable, we are targeting publications between 2010 and 2021. Because of the data we obtained through publication, we call this secondary study data and following the implementation period in the pandemic era with all the limitations of field movements. We guide qualitative studies such as Azungah (2018) in data qualitative study design for a deductive and inductive technique to study analysis.

\section{Results and Discussions}

With an understanding of HR governance for government administrative employees, as referred to above, Yohana (2019) admits that there are still low human resources for government administrators in the regions. From speculation, welfare, and training administrators, it can be seen that the limited human assets of government administrators are still low. The minimum limit of human assets for administrative services is in the venture business as much as $55.04 \%$; then the second is health services $36.77 \%$ and instruction services 36.5\% (Mariano, 2018). In connection with these

Hidir, A., Zunaidi, A., \& Pattiasina, P. J. (2021). Understanding human resources management strategy in implementing good government practice: what research evidence say. International Research Journal of Management, IT and Social Sciences, 8(3), 265-273. https://doi.org/10.21744/irjmis.v8n3.1658 
different problems, developing policies and strategies for developing the quality of public services is planned to recognize the boundary state of public service human assets at every competency angle (Azzindani \& Irwan, 2020). Furthermore, it can distinguish the efforts of administrative units in expanding the boundaries of public service human resources and detailing strategic proposals and methodologies for building HR boundaries in future governments to develop sustainable public administration characteristics (Pardo et al., 2010).

This understanding of public service human resources is centered on (1) how high the status of the HR apparatus asset limit is related to each part of health services (Aarons et al., 2011). How to make arrangements and methodologies to establish HR administrative boundaries and the factors that support/prevent the improvement of approaches and procedures to expand the boundaries of public service HR so that the results obtained from this exam are able as a whole from a competency perspective that should be controlled by open service HR generally indicating an undeniable degree. However, from all aspects of HR competency that must be controlled, according to Siti Maryam (2017) which is capable of realizing good governance through fair and sustainable community services, there are four competency points of view, most of which receive a generally low assessment, such as the capacity of utilization technology, capacity in setting work guidelines and Standard services, responsibility in rewarding and discipline, and understanding of organizational strategy and vision (Picazo-Vela et al., 2012). The four loci for examining improved approaches and techniques for increasing HR boundaries for administration are remarkable, but overall, part of the methodology employed is in unique and temporary positions in some areas where governance is extraordinary (Beare et al., 1989).

Indeed, several fields have led to similar investigations to determine how understanding HR works openly in administrative units in certain countries (Festing, 2012). The use of unique uniforms to give an impression of friendliness, such as in government offices and the usual presence of aid units are other procedures for improving the nature of government administration. Several regions have also led the preparation of character systems and administration as a team with several extension agencies in public administration regarding behavior improvement. Based on the above objectives, the suggestions that can be given in this study are general suggestions. HRM works in the public area becomes very basic and unique to the private area (DeCenzo et al., 2016). Indeed, the ideas created in HRM originate from private area business training. For organizations such as government institutions, HRM is not just an instrument of the use of representation. HRM in the private area alone, as expressed by Rahman et al. (2018) is also a source of solidarity for organizations in achieving excellence in the current era of management transparency; HRM must be able to function adequately in the private area, while in reality it is not yet maximized. In the public service area of Rahman et al. (2018). One of the determining elements for the sustainability of HRM relates to the hierarchical culture of the private area, which is a striking difference from the public area. In addition to culture, the unfavorable authoritative environment and administrative qualities that are not relevant to change become regulatory barriers to achieving hierarchical continuity as recognized by Cooke \& Lin (2012) who inspect public area associations and police in many developed countries. The world of science and experts must describe HRM in the way of life, authoritative environment, and the administrative qualities typical of organizations that are not precisely the same as organizations dealing with personal areas (Carlitz \& Povitkina, 2021).

With a belief in the view that culture and hierarchical environment and administrative quality can support the achievement of authoritative excellence as developed by Tomaževič et al. (2017) this paper is proposed to illustrate the miracle and prologue for the advancement of HRM models in the public area so that they tend to be used as sources perspective to build a strong organization in offering the types of assistance that help increase the intensity of the Indonesian state. HRM as a whole can be seen from the importance of its framework and capacity. Regarding the importance of a framework, HRM is only an administrative framework that is deliberately intended to ensure that the potential or abilities of all people in the relationship can be used appropriately and effectively (Jiang et al., 2012).

The use of these people is planned to achieve the goals and targets set by the association (Boxall \& Purcell, 2011). The science of logic is one of the logical arrangements which significantly adds to the association to plan a single potential to be adequately realized in support of the execution of the work. The framework is then executed into several HRM capacities that, in the long run, a complete definition of HRM structure is useful, particularly "all exercises beginning with HR that are meant to pretend or end HR." Among other essential exercises after capacity regulation and before the end of HR are the readiness of job investigations, HR registration followed by the determination and arrangement of HR in related positions, then gradually financial elements, implementation inspection, preparation, and quality improvement. The profession of executives in positions, fostering worker connections, such as planning various work-life programs. However, HRM is not clear enough about the framework and capacities. HRM will have broader importance for association from a regulatory perspective (Jackson et al., 2014).

When examined from a strategic point of view, traditional HRM, as developed by Sunarsi (2018) implies a type of hierarchical arrangement deliberately intended to increase the mix of each authoritative component, build worker 
obligations to associations, adaptability standards in capacity implementation. Administration and work to move away from being independent, as is the achievement of good values as far as the cycle of execution and consequences of work. From this strategic perspective, an idea eventually developed that the full significance of HRM is not limited in a specialized sense. Apart from specific problems, HRM has also experienced job unions that are more generous. The integration of jobs experienced by HRM has been going on since the 2000s. Meanwhile, the latest trend model from Cooke \& Lin (2012) where HRM in China is becoming a new color in several other countries where the HRM section experiences a combination, is planned to react to ecological changes with various difficulties and demands.

In other contexts, HRM has a mission to offer assistance to HRs to assist with information for HR, build good communication for all gatherings and have a unique ability to beat each other issue associations are appropriate and fast. Basic Principles of Human Resources Public areas have the same standards as private areas in carrying out administrative capacities. Due to the hierarchical climate created with greatly improved elements during the 1990s, administrative capacity is aimed at creating a single behavior concerning general rules emphasized by Kaufman (2020) where HRM is increasingly global and convergence-divergence of HRM across nations, this requires new figures and evaluations that can explain theories, and non-standard predictions from bringing in economics that hold a point of view, in particular, such as an emphasis on individuals, participatory authority, innovative work styles, vital customer goals and a vision that seeks execution. Ideal and balanced by Meyer \& Hammerschmid (2010) where the degree of decentralization and individual decisions are more focused on central government HRM.

In reality, Berman et al. (2019) believe that HRM in public service becomes paradoxes and problems so that the association is present to deal with human problems. Meanwhile, in human resources, the association clearly shows the community's situation as the main component in it. In this way, the human component in the relationship is inactive and dynamic in facing various difficulties and is prepared to create actual social coherence. As distinguished by Tarigan (2017) in his study of the role of the National Narcotics Agency and Community Social Organizations in Handling Drug Abuse Perpetrators was relevant. In his review, he assessed that the increase in HR scores depended on the side effects of various investigations received to improve hierarchical execution. HRM has participatory administration rules. If we look at the primary HRM standards that position the human component as a functional group, then the following rules also position pioneers as a functional group and not only situational (DeCenzo et al., 2016). In theory, the best administration is to adapt to all developments in the situational structure (Tyson, 2014). However, most elite administration is the ability to adapt to the pioneers effectively, along with an increased level of self-association at all levels of association and with the capacity to form an inventive climate (Armstrong, 2011). The third basic rule of HRM refers to creative behavior that does not stop at the results a person can achieve. This third standard refers to a person's ability to choose to consider an exhibition (Armstrong \& Taylor, 2020). That has been carried out and then study it so that later he wants to get to a higher level. As the level of competition increases, the general direction of the association will be outward. In this arrangement, consumer loyalty and for the public area is a goal and an "instrument" for the association to achieve excellence, which is supported by the public Noe et al. (2017) in their work of HRM winning competitive benefits.

Understanding the four rules of HRM in the public service environment assumes an essential part in a period of asset shortage, increasingly limited and incredibly accessible assets. At the same time, demand from local areas that utilize goods and authoritative administration progressively shifts so that the requirements for assets expand (Theriou \& Chatzoglou, 2014). Meanwhile, the fifth standard in HRM still places the individual focal figure as a person with various honorable qualities that can guide him to various improvement efforts. The mentality is an essential idea for demonstrating that people's insights, perspectives, and behaviors have an excellent direction in building authoritative achievement. Engagement with various countries shows that authoritative greatness can be achieved through enhancing human assets. Zhou \& Wang (2014) as an instrument to win opposition and make progress. Next, HRM standards are an essential exercise in building quality associations based on improving HR (Noe et al., 2017).

These HRM standards also emphasize that without quality human resources, an association cannot make progress at all. Public Sector HRM: The Dominant Role Classically, public area HRM has been an essential part of any push to change organizations in offering the type of assistance to solve problems and the convenience of various interests and government assistance from people who have the character and boundaries that make them eligible for such assistance; and the capacity, achievement, and character essential for the correct discharge of obligations of any kind - overall, the individual's advantage over competitors - is itself the most crucial case in office (Sharma et al., 2011).

The achievement of regulatory changes can be started from the actual reality of the organization in handling its human resources. Therefore, this is an ideal opportunity for the government in Indonesia not to haggle on registration, job options, and situations or positions for staff and authorities, evaluation of implementation, revolutions, and

Hidir, A., Zunaidi, A., \& Pattiasina, P. J. (2021). Understanding human resources management strategy in implementing good government practice: what research evidence say. International Research Journal of Management, IT and Social Sciences, 8(3), 265-273. https://doi.org/10.21744/irjmis.v8n3.1658 
movements to establish a single boundary, character, and capability. All HRM capacities must be carried out strictly and fairly (Berman et al., 2019).

\section{Conclusion}

We can say that we have answered the questions of this study as validly as desired by this study by presenting and discussing the results. Understanding the role of HR governance in the public service sector has become a unified view of [experts as we described in the data. This is following our opinion that public services in the era of transparency and reform require updating and sustainable human resource management so that managers of organizations and public institutions get high trust from the public that they believe in their approach to knowledge skills and conformity to values and dedication to their work to serve the public and living now in a free and democratic era.

Conflict of interest statement

The author(s) declared that they have no competing interests.

Statement of authorship

The author(s) have a responsibility for the conception and design of the study. The author(s) have approved the final article.

\section{Acknowledgments}

We authors would like to extend our thousands of thanks to all the support from our academic colleagues who helped us from the early stages up to the reporting of this study. Likewise, we appreciate the financial support from the ministry of technology and research so that this project is ready according to the plan. Hopefully, next time we can continue to contribute even more. 


\section{References}

Aarons, G. A., Hurlburt, M., \& Horwitz, S. M. (2011). Advancing a conceptual model of evidence-based practice implementation in public service sectors. Administration and Policy in Mental Health and Mental Health Services Research, 38(1), 4-23.

Ahmed, A., Abu-Naser, S. S., El Talla, S. A., \& Al Shobaki, M. J. (2018). The Impact of Information Technology Used on the Nature of Administrators Work at Al-Azhar University in Gaza.

Al Shobaki, M. J., Naser, S. S. A., Amuna, Y. M. A., \& El Talla, S. A. (2017). Impact of Electronic Human Resources Management on the Development of Electronic Educational Services in the Universities. International Journal of Engineering and Information Systems, 1(1), 1-19.

Armstrong, M. (2011). Armstrong's handbook of strategic human resource management. Kogan Page Publishers.

Armstrong, M., \& Taylor, S. (2020). Armstrong's handbook of human resource management practice.

Ashari, E. T. (2010). Reformasi Pengelolaan SDM Aparatur, Prasyarat Tata Kelola Birokrasi Yang Baik. Jurnal Borneo Administrator, 6(2).

Anderson, D. K., \& Merna, T. (2003). Project management strategy-project management represented as a process based set of management domains and the consequences for project management strategy. International Journal of Project Management, 21(6), 387-393. https://doi.org/10.1016/S0263-7863(02)00087-X

Azungah, T. (2018). Qualitative research: Deductive and inductive approaches to data analysis. Qualitative Research Journal.

Azzindani, R., \& Irwan, M. (2020). Implementasi SIMDA dan Kinerja Aparatur Pemerintah Daerah Terhadap Kualitas Laporan Keuangan Dimediasi Good Government Governance. Akurasi: Jurnal Studi Akuntansi Dan Keuangan, 3(1), 31-54.

Bailey, C., Mankin, D., Kelliher, C., \& Garavan, T. (2018). Strategic human resource management. Oxford University Press.

Battaglio Jr, R. P. (2014). Public Human Resource Management. Sage.

Beare, H., Caldwell, B. J., \& Millikan, R. H. (1989). Creating an excellent school: Some new management techniques. Routledge.

Berman, E. M., Bowman, J. S., West, J. P., \& Van Wart, M. R. (2019). Human resource management in public service: Paradoxes, processes, and problems. CQ Press.

Boxall, P., \& Purcell, J. (2011). Strategy and human resource management. Macmillan International Higher Education.

Carlitz, R. D., \& Povitkina, M. (2021). Local interest group activity and environmental degradation in authoritarian regimes. World Development, 142, 105425.

Cooke, F. L., \& Lin, Z. (2012). Chinese firms in V ietnam: Investment motives, institutional environment and human resource challenges. Asia Pacific Journal of Human Resources, 50(2), 205-226.

Choi, B., \& Lee, H. (2002). Knowledge management strategy and its link to knowledge creation process. Expert Systems with applications, 23(3), 173-187. https://doi.org/10.1016/S0957-4174(02)00038-6

Cui, Z., Zhang, F., Chen, X., Miao, Y., Li, J., Shi, L., .. \& Bao, D. (2008). On-farm evaluation of an in-season nitrogen management strategy based on soil Nmin test. Field Crops Research, 105(1-2), 48-55. https://doi.org/10.1016/j.fcr.2007.07.008

DeCenzo, D. A., Robbins, S. P., \& Verhulst, S. L. (2016). Fundamentals of human resource management. John Wiley \& Sons.

Denhardt, R. B., Denhardt, J. V., \& Blanc, T. A. (2013). Public administration: An action orientation. Cengage Learning.

Festing, M. (2012). Strategic human resource management in Germany: Evidence of convergence to the US model, the European model, or a distinctive national model? Academy of Management Perspectives, 26(2), 37-54.

Fridayanti, H., Indyastuti, D. L., \& Anggraeni, A. I. (2019). The Effect Of Work-Family Conflict On Job Stress Of Country Civil Apparatus With Locus Of Control As A Moderation. ICORE, 5(1).

Gao, D., Jin, Z., \& Lu, Q. (2008). Energy management strategy based on fuzzy logic for a fuel cell hybrid bus. Journal of Power Sources, 185(1), 311-317. https://doi.org/10.1016/j.jpowsour.2008.06.083

Heady, F. (2001). Public Administration, A Comparative Perspective. CRC Press.

Hemi, H., Ghouili, J., \& Cheriti, A. (2014). A real time fuzzy logic power management strategy for a fuel cell vehicle. Energy conversion and Management, 80, 63-70. https://doi.org/10.1016/j.enconman.2013.12.040

Jackson, S. E., Schuler, R. S., \& Jiang, K. (2014). An aspirational framework for strategic human resource management. Academy of Management Annals, 8(1), 1-56.

Hidir, A., Zunaidi, A., \& Pattiasina, P. J. (2021). Understanding human resources management strategy in implementing good government practice: what research evidence say. International Research Journal of Management, IT and Social Sciences, 8(3), 265-273. https://doi.org/10.21744/irjmis.v8n3.1658 
Jiang, K., Lepak, D. P., Han, K., Hong, Y., Kim, A., \& Winkler, A.-L. (2012). Clarifying the construct of human resource systems: Relating human resource management to employee performance. Human Resource Management Review, 22(2), 73-85.

Kaufman, B. E. (2020). The real problem: The deadly combination of psychologisation, scientism, and normative promotionalism takes strategic human resource management down a 30-year dead end. Human Resource Management Journal, 30(1), 49-72.

Larsen, M., \& Piché, J. (2009). Exceptional state, pragmatic bureaucracy, and indefinite detention: The case of the Kingston Immigration Holding Centre. Can. JL \& Soc., 24, 203.

Mahsyar, A. (2011). Masalah pelayanan publik di Indonesia dalam perspektif administrasi publik. Otoritas: Jurnal Ilmu Pemerintahan, 1(2).

Mariano, S. (2018). Penerapan E-Government Dalam Peningkatan Pelayanan Publik Di Kabupaten Sidoarjo [PhD Thesis]. Universitas Airlangga.

Mello, J. A. (2014). Strategic human resource management. Cengage Learning.

Meyer, R. E., \& Hammerschmid, G. (2010). The degree of decentralization and individual decision making in central government human resource management: A European comparative perspective. Public Administration, 88(2), $455-478$.

Noe, R. A., Hollenbeck, J. R., Gerhart, B., \& Wright, P. M. (2017). Human resource management: Gaining a competitive advantage. McGraw-Hill Education New York, NY.

Osborne, S. P., \& Brown, K. (2005). Managing change and innovation in public service organizations (Vol. 1). Routledge London.

Pardo, T. A., Gil-Garcia, J. R., \& Luna-Reyes, L. F. (2010). Collaborative governance and cross-boundary information sharing: Envisioning a networked and IT-enabled public administration. The Future of Public Administration around the World: The Minnowbrook Perspective, 129-139.

Picazo-Vela, S., Gutiérrez-Martínez, I., \& Luna-Reyes, L. F. (2012). Understanding risks, benefits, and strategic alternatives of social media applications in the public sector. Government Information Quarterly, 29(4), 504-511.

Putra, R. M. D. (2018). Inovasi Pelayanan Publik Di Era Disrupsi (Studi Tentang Keberlanjutan Inovasi E-Health Di Kota Surabaya) [PhD Thesis]. Universitas Airlangga.

Rahmadana, M. F., Mawati, A. T., Siagian, N., Perangin-angin, M. A., Refelino, J., Tojiri, M. Y., Siagian, V., Nugraha, N. A., Manullang, S. O., \& Silalahi, M. (2020). Pelayanan Publik. Yayasan Kita Menulis.

Rahman, M., Mordi, C., \& Nwagbara, U. (2018). Factors influencing E-HRM implementation in government organisations. Journal of Enterprise Information Management.

Rao, C. (2013). The Reform and Development of Teacher Education in China and Japan in an Era of Social Change: Trends and Issues. In Transforming Teachers' Work Globally (pp. 261-301). Brill Sense.

Raudeliūnienè, J., \& Meidutè-Kavaliauskienè, I. (2014). Analysis of factors motivating human resources in public sector. Procedia-Social and Behavioral Sciences, 110, 719-726.

Ristiandy, R. (2020). Bureaucratic Disruption and Threats of Unemployment in the Industrial Revolution 4.0 Era. Journal of Local Government Issues (LOGOS), 3(1), 86-97.

Seleman, M., Chapy, H., Cisternino, S., Courtin, C., Smirnova, M., Schlatter, J., Chiadmi, F., Scherrmann, J.-M., Noble, F., \& Marie-Claire, C. (2014). Impact of P-glycoprotein at the blood-brain barrier on the uptake of heroin and its main metabolites: Behavioral effects and consequences on the transcriptional responses and reinforcing properties. Psychopharmacology, 231(16), 3139-3149.

Sharma, S., Sharma, J., \& Devi, A. (2011). Corporate social responsibility: The key role of human resources management. Human Resource Management: Issues, Challenges and Opportunities, 9.

Siti Maryam, N. (2017). Mewujudkan good governance melalui pelayanan publik. JIPSI-Jurnal Ilmu Politik Dan Komunikasi UNIKOM, 6.

Storey, J. (2016). Human resource management. Edward Elgar Publishing Limited.

Suderajat, H. (2012). Pengembangan Sistem Manajemen Sumber Daya Manusia Aparatur Pemerintah Daerah. Ilmu Dan Budaya, 32(23).

Sukati, I., Hamid, A. B., Baharun, R., \& Yusoff, R. M. (2012). The study of supply chain management strategy and practices on supply chain performance. Procedia-Social and Behavioral Sciences, 40, 225-233. https://doi.org/10.1016/j.sbspro.2012.03.185

Sunarsi, D. (2018). Pengembangan Sumber Daya Manusia Strategik \& Karakterisrik Sistem Pendukungnya: Sebuah Tinjauan. Jurnal Ilmiah MEA (Manajemen, Ekonomi, \& Akuntansi), 2(3), 178-194. 
Syakdiyah, A., Nurmahmudah, F., \& Wijayanti, W. (2019). Active Learner Strategies in Era of Disruption: A Literature Review. First International Conference on Progressive Civil Society (ICONPROCS 2019), 165-168.

Tarigan, I. J. (2017). Peran Badan Narkotika Nasional dengan Organisasi Sosial Kemasyarakatan dalam Penanganan Pelaku Penyalahgunaan Narkotika. Deepublish.

Theriou, G. N., \& Chatzoglou, P. (2014). The impact of best HRM practices on performance-identifying enabling factors. Employee Relations.

Tomaževič, N., Tekavčič, M., \& Peljhan, D. (2017). Towards excellence in public administration: Organisation theorybased performance management model. Total Quality Management \& Business Excellence, 28(5-6), 578-599. https://doi.org/10.1080/14783363.2015.1102048

Truss, C., Shantz, A., Soane, E., Alfes, K., \& Delbridge, R. (2013). Employee engagement, organisational performance and individual well-being: Exploring the evidence, developing the theory. Taylor \& Francis.

Tyson, L. (2014). Critical theory today: A user-friendly guide. Routledge.

Yahya, A., Majid, S. A., \& Din, M. (2020). Career Development of Civil Servants in the Autonomy Era in Indonesia. International Conference on Law, Governance and Islamic Society (ICOLGIS 2019), 231-240.

Yohana, Y. I. A. (2019). Kualitas sumber daya manusia dalam meningkatkan kinerja pemerintah desa Penelitian Deskriptif Kualttatif Di Desa Pulau Jaya Kecamatan Tempunak Kabupaten Sintang Provinsi Kalirnantan Barat.

Zhou, L., \& Wang, T. (2014). Social media: A new vehicle for city marketing in China. Cities, 37, $27-32$.

Hidir, A., Zunaidi, A., \& Pattiasina, P. J. (2021). Understanding human resources management strategy in implementing good government practice: what research evidence say. International Research Journal of Management, IT and Social Sciences, 8(3), 265-273. https://doi.org/10.21744/irjmis.v8n3.1658 